\title{
Advantages of the Product Diversification Strategy in Beekeeping Farms
}

\author{
Anca A. POPOVICI*1), Liviu Al. MĂRGHITAŞ ${ }^{1)}$, Daniel S. DEZMIREAN ${ }^{1)}$, Marioara ILEA ${ }^{2)}$ \\ ${ }^{1)}$ Faculty of Animal Science and Biotechnologies, University of Agricultural Sciences and Veterinary \\ Medicine, 3-5 Mănăştur Street, 400372 Cluj-Napoca, Romania \\ ${ }^{2)}$ Faculty of Horticulture, University of Agricultural Sciences and Veterinary Medicine, 3-5 Mănăştur \\ Street, 400372 Cluj-Napoca, Romania \\ *Corresponding author, email; anca.popovici@usamvcluj.ro
}

Bulletin UASVM Animal Science and Biotechnologies 71(2) / 2014,

Print ISSN 1843-5262; Electronic ISSN 1843-536X

DOI:10.15835/buasvmcn-asb:10343

\begin{abstract}
The purpose of the research is to shape the main benefits and motivations of Romanian beekeepers, which manage a beekeeping farm and implement the diversification strategy. Interviews were performed with 20 managers of beekeeping farms from the North-West Region of Romania. Results point out that the main advantages of the production diversification strategy are the ability to respond to the opportunities that arise on the market, the involvement of farm owners and employees in different activities related to production throughout the year (they can live at the farm and work during the winter season), as well as professional satisfaction. The diversification strategy determine the competitive advantage of beekeeping farms and lies in the unique combination of different products specific to each farm, which differentiates it from its competitors.
\end{abstract}

Keywords: advantages, diversification, motivations, beekeeping farms

Introduction. In order for beekeeping farms to be profitable, different strategies can be adopted such as product diversification. A survey on a sample of 420 beekeepers from the NorthWest Region of Romania in 2011 emphasized the fact that $51 \%$ of beekeepers implement the diversification strategy within their beekeeping farms and the main factors that influence the diversification strategy are owning a personal shop and addressing domestic markets (Popovici and Mărghitaş, 2013). The diversification of beekeeping products is critical to the diversification of beekeepers' income and adds value to the hive products (Ingram and Njikeu, 2011).

Aims and objectives. The present study aims to identify beekeepers' motivations and advantages of adopting the product diversification strategy within their apiaries. The objectives of the research consist in conducting a set of interviews with managers of beekeeping farms so as to determine the main benefits of the product diversification strategy.
Materials and methods. Data were collected through semi-structured interviews with 20 managers of beekeeping farms from the NorthWest Region of Romania.

Results and discussion. The diversification strategy aims at achieving various high quality products, primarily taking into account customers' requirements. Beekeepers' entrepreneurial orientation involves diversification, bringing new products to the market. The beekeeping enterprises under study sell a variety of high quality products: honey, pollen obtained from many types of plants (raspberries, hawthorn, oak, willow, colza, chestnut and maple), propolis, wax, packages (a box of worker bees used to set up a new colony), queens, combs, hives, wax candles, different types of honey such as eucalyptus honey, chestnut honey, rosemary honey, lemon honey, lavender honey, honey with goji, candies with honey, wine with honey and propolis; different types of cosmetics: moisturizer, eye contour cream, regenerating night cream, anti-wrinkle cream, 
nutritional day cream, nutritional hands cream, foot care cream, lip balm, balm with propolis and beeswax, mouthwash with propolis, vegetable based soaps with honey and pollen.

The entrepreneurial orientation of the beekeeping farms emerges from their new product release during the last 5 years and current investment in the development of new products.

Their strategy for achieving a competitive advantage is based on understanding the needs of bee products consumers. To this purpose, the interviewed beekeepers ask their customers at least once a year to state their opinion concerning the quality of their bee products.

Beekeeping farms achieve a competitive advantage by creating innovative, diversified, high quality products. The competitive advantage lies in the multitude of products sold, a unique combination of different products specific to each farm, which differentiates them from their competitors. The main advantages of the product diversification strategy identified are the farm's ability to respond to the opportunities that arise on the market, the fact that farm owners and employees are involved in different activities related to production throughout the year (they can live at the farm and work during the winter season) as well as professional satisfaction. The findings of the current study are consistent with those that state that off-farm and farm-related diversifiers are more likely to be motivated by a desire to make it possible to live at the farm and to meet people than they are by a "need for additional income" (Vik and McElwee, 2011). Another reason for diversification is consumers' tendency to purchase products that offer health benefits.

Conclusion. Due to production diversification, beekeeping farms are able to identify new market opportunities and afterwards allocate resources to exploit these opportunities. When deciding for the business strategies to be adopted, the beekeeping farms take into account the opportunities discovered in the external environment. Their competitive advantage lies in the various products offered to the market in a unique combination specific to each farm. The beekeeping farms efficiently combine the development of different types of products with the rearing of queen bees, making frames, hives etc., in some cases the whole family being involved in these activities.

Acknowledgements. This paper was published under the frame of European Social Fund, Human Resources Development Operational Programme 2007-2013, projectno. POSDRU/159/1.5/S/132765.

\section{REFERENCES}

1. Ingram V and J Njikeu (2011). Sweet, Sticky and Sustainable Social Business. Ecology \& Society. 16(1): 37.

2. Popovici A and L Mărghitaş (2013). Entrepreneurship in the beekeeping sector. Edit. Academic Pres. ClujNapoca.132-133.

3. Vik J and G McElwee (2011). Diversification and the Entrepreneurial Motivations of Farmers in Norway, Journal of Small Business Management. 49 (3): 390-410. 